\title{
Pore forming polyalkylpyridinium salts from marine sponges versus synthetic lipofection systems: distinct tools for intracellular delivery of cDNA and siRNA
}

\author{
Debra McLaggan ${ }^{1}$, Noppadon Adjimatera ${ }^{2}$, Kristina Sepčićc ${ }^{3}$, Marcel Jaspars ${ }^{4}$, \\ David J MacEwan ${ }^{5}$, Ian S Blagbrough ${ }^{2}$ and Roderick H Scott*1
}

Address: ${ }^{1}$ School of Medical Sciences, College of Life Sciences and Medicine, University of Aberdeen, Institute of Medical Sciences, Foresterhill, Aberdeen AB25 2ZD, UK, ${ }^{2}$ Department of Pharmacy and Pharmacology, University of Bath, Claverton Down, Bath BA2 7AY, UK, ${ }^{3}$ Department of Biology, Biotechnical Faculty, University of Ljubljana, Veèna pot 111, 1000 Ljubljana, Slovenia, ${ }^{4}$ Marine Natural Products Laboratory, Department of Chemistry, University of Aberdeen, Aberdeen AB24 3UE, UK and ${ }^{5}$ School of Chemical Sciences and Pharmacy, University of East Anglia, Norwich, NR4 7TJ, UK

Email: Debra McLaggan - debbie@cabernet.demon.co.uk; Noppadon Adjimatera - prpna@bath.ac.uk; Kristina Sepčić - kristina.sepcic@bf.unilj.si; Marcel Jaspars - m.jaspars@abdn.ac.uk; David J MacEwan - d.macewan@uea.ac.uk; Ian S Blagbrough - i.s.blagbrough@bath.ac.uk; Roderick H Scott* - rod.scott@abdn.ac.uk

* Corresponding author

Published: 16 January 2006

BMC Biotechnology 2006, 6:6 doi:10.1186/1472-6750-6-6

This article is available from: http://www.biomedcentral.com//472-6750/6/6

(C) 2006 McLaggan et al; licensee BioMed Central Ltd.

This is an Open Access article distributed under the terms of the Creative Commons Attribution License (http://creativecommons.org/licenses/by/2.0), which permits unrestricted use, distribution, and reproduction in any medium, provided the original work is properly cited.

\begin{abstract}
Background: Haplosclerid marine sponges produce pore forming polyalkylpyridinium salts (polyAPS), which can be used to deliver macromolecules into cells. The aim of this study was to investigate the delivery of DNA, siRNA and lucifer yellow into cells mediated by poly-APS and its potential mechanisms as compared with other lipofection systems (lipofectamine and $\mathrm{N}^{4}, \mathrm{~N}^{9}$ dioleoylspermine (LipoGen)). DNA condensation was evaluated and HEK 293 and HtTA HeLa cells were used to investigate pore formation and intracellular delivery of cDNA, siRNA and lucifer yellow.
\end{abstract}

Results: Poly-APS and LipoGen were both found to be highly efficient DNA condensing agents. Fura-2 calcium imaging was used to measure calcium transients indicative of cell membrane pore forming activity. Calcium transients were evoked by poly-APS but not LipoGen and lipofectamine. The increases in intracellular calcium produced by poly-APS showed temperature sensitivity with greater responses being observed at $12{ }^{\circ} \mathrm{C}$ compared to $21^{\circ} \mathrm{C}$. Similarly, delivery of lucifer yellow into cells with poly-APS was enhanced at lower temperatures. Transfection with cDNA encoding for the expression enhanced green fluorescent protein was also evaluated at $12^{\circ} \mathrm{C}$ with poly-APS, lipofectamine and LipoGen. Intracellular delivery of siRNA was achieved with knockdown in betaactin expression when lipofectamine and LipoGen were used as transfection reagents. However, intracellular delivery of siRNA was not achieved with poly-APS.

Conclusion: Poly-APS mediated pore formation is critical to its activity as a transfection reagent, but lipofection systems utilise distinct mechanisms to enable delivery of DNA and siRNA into cells. 


\section{Background}

The technologies investigated in this study involved the use of polymeric alkylpyridinium sponge toxins, (polyalkylpyridinium salts; poly-APS) [1-3]. Poly-APS is a marine toxin preparation extracted from the sponge Reniera sarai, which can form reversible pores or lesions in cell membranes [1]. This toxin preparation primarily contains a cocktail of two polymeric 1,3-octylpyridinium salts of 5.5 and $19 \mathrm{kDa}$ sizes [4]. At a high concentration $(50 \mu \mathrm{g} /$ $\mathrm{ml}$ ), polyalkylpyridinium salts can cause irreversible depolarisation in membrane potential and a collapse in input resistance. However, at lower concentrations (0.5 $\mu \mathrm{g} / \mathrm{ml}$ ) poly-APS show reversible actions on the electrophysiological properties and $\mathrm{Ca}^{2+}$ permeability in HEK 293 cells, dorsal root ganglion neurons and F-11 cells. The unique pore formation properties in addition to their poly-positive charged characteristics, could be useful in non-viral gene therapy (NVGT) applications. In a previous study [2] some us have shown that sponge toxins can be used to deliver cDNA into HEK293 cells and that this results in the expression of the protein encoded by these genes. Furthermore, the co-transfection of cDNA is stable and colonies of cells can be produced that contain polyAPS delivered CDNA and the proteins they encode for [2]. However, there has to date been no reported study on the interaction of this polycationic toxin with DNA and further information is required on the mechanism of transfection and the versatility of macromolecule (DNA or siRNA) delivery. This is particularly important given that our data suggest membrane poration is required for polyAPS-mediated transfection because low molecular weight pyridinium surfactant monomers and dimers can also be efficient non-toxic agents for gene delivery [8]. However, in contrast, pyridinium surfactant monomers are not efficient pore formers and appear to package DNA for delivery by fusion and/or endocytosis.

The aims of our study were to explore the DNA condensation properties and temperature sensitivity of their gene delivery mechanism(s). In addition, the aims were extended to the delivery, using poly-APS, of small interfering RNA (siRNA) into cells and thus to the knockdown of gene expression. Comparisons are made with the activity of LipoGen, a synthetic lipospermine (see Figure 1) an efficient DNA delivery agent [5-7], and lipofectamine, a commercially available transfection reagent.

\section{Results}

\section{DNA condensation study of poly-APS and LipoGen}

The DNA condensation experiments were run with a plasmid encoding for enhanced green fluorescent protein (pEGFP) or luciferase (pGL3), and with calf thymus DNA (ctDNA). In DNA condensation experiments, ethidium bromide (EthBr), a DNA intercalating cationic dye was used as a fluorescent probe. This intercalation increases
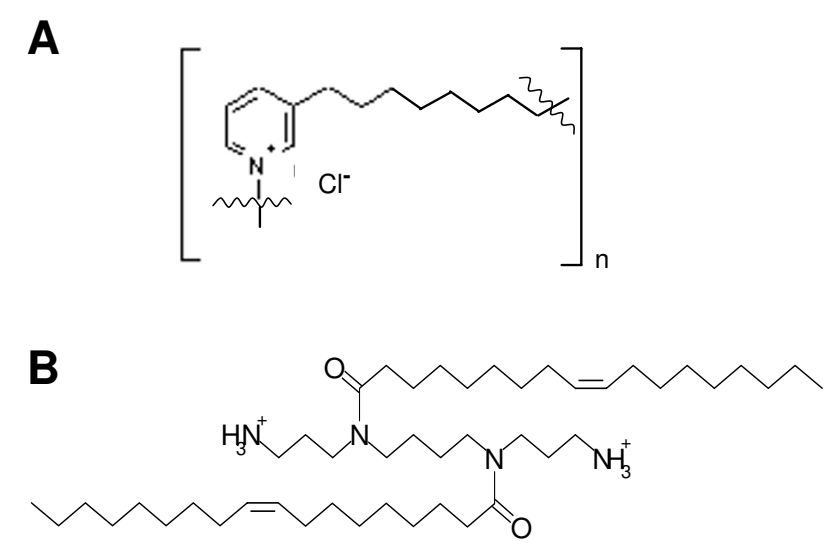

Figure I

Structures of transfection reagents and other related molecules of interest. A, polymeric alkylpyridinium salt (poly-APS) a sponge toxin preparation composed of a mixture of two polymeric I,3-octylpyridinium salts of $5.5(n=29$ average) and $19 \mathrm{kDa}\left(\mathrm{n}=99\right.$ average) sizes. $\mathrm{B}, N^{4}, N^{9}$-dioleoylspermine (LipoGen).

the fluorescence yield of EthBr (excitation $546 \mathrm{~nm}$, emission $595 \mathrm{~nm}$ ). Many compounds that bind to DNA, including DNA condensing agents used in NVGT, can displace EthBr from EthBr-DNA complexes. EthBr has been widely used to assess the DNA-polyamine complex formation efficiently $[9,10]$. In 2000, a modified reproducible EthBr displacement assay was reported by Geall and Blagbrough [9]. The excitation wavelength was optimised at $260 \mathrm{~nm}$ [11] where EthBr is indirectly excited by energy transfer from the DNA. The proposed protocol also allows the experiment to be run without pre-complexing DNA and its binding molecule, a "displacement assay" [9]. The DNA condensed particle formation has been measured at UV absorbance of $320 \mathrm{~nm}$ [12]. The double-helical DNA was bound by polyamines and formed nanoparticles, which scatter the light resulting in the UV absorbance increase above $300 \mathrm{~nm}$. Light scattering (LS) is measured rather than UV absorption (no chromophore for this wavelength). A little precipitation of the DNA may be visible, but it does not increase the absorption above 300 $\mathrm{nm}$. The DNA concentration used in this assay was a 10fold excess compared to the EthBr assay given the low sensitivity of this experimental system and lack of fluorescence indicator.

Both poly-APS and LipoGen (Figure 1) were able to condense pEGFP, pGL3, and ctDNA efficiently with residual fluorescence at $10 \%$ in ethidium bromide (EthBr) assay (Figure 2A,B). The increase of UV absorption was also confirmed by light scattering experiments, indicating DNA nanoparticle formation (Figure 2C,D). Optimal N/P 
A

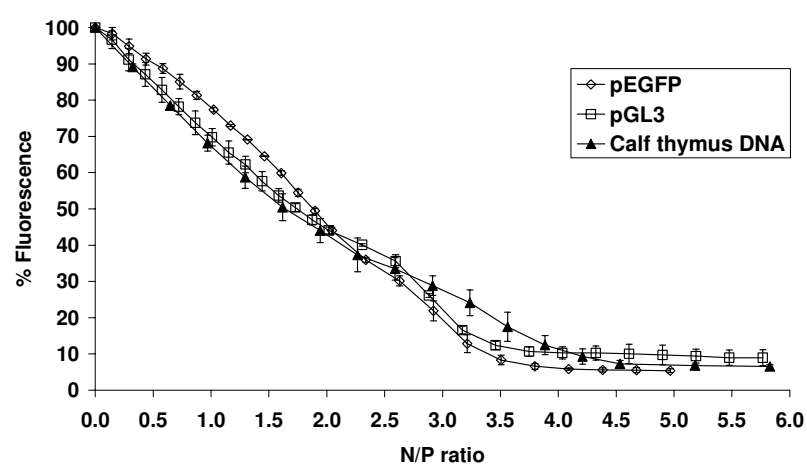

C

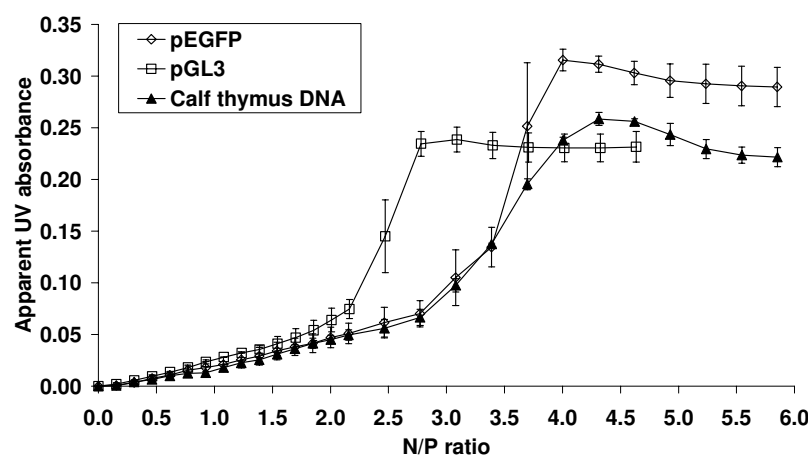

B

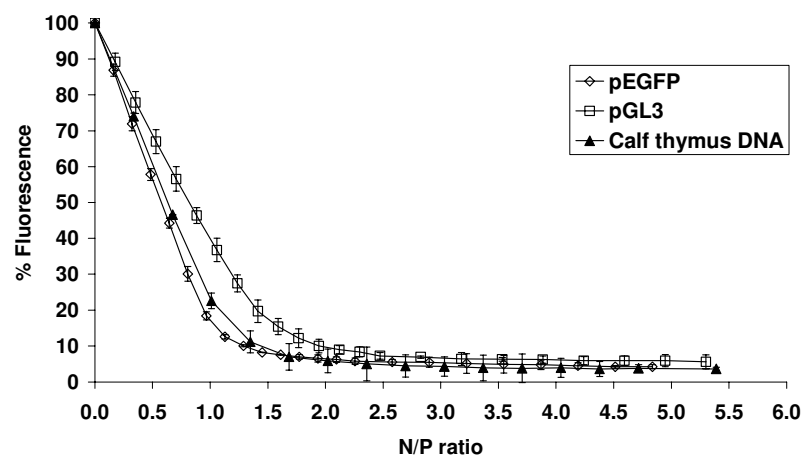

D

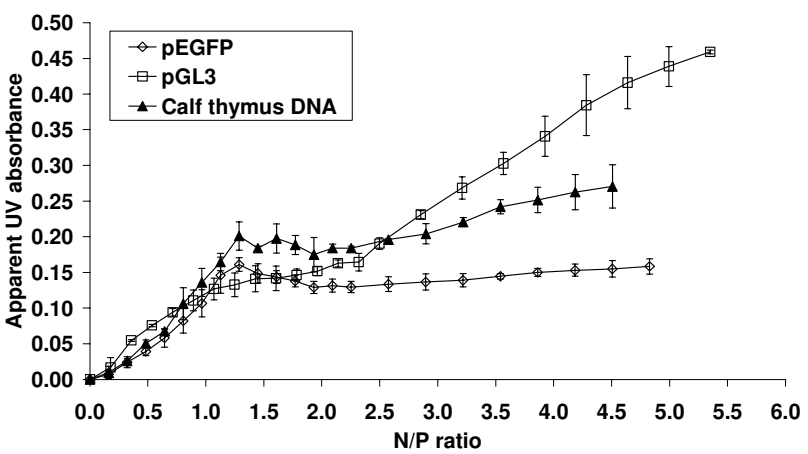

Figure 2

DNA condensation profile of poly APS and LipoGen using different DNA; pEGFP (4.7 kilobase pairs), pGL3 (5.3 kilobase pairs) and calf thymus DNA ( 13 kilobase pairs), using ethidium bromide displacement and light scattering assays. Ethidium bromide assay shows a decrease of fluorescence intensity (excitation at $260 \mathrm{~nm}$, and emission at $600 \mathrm{~nm}$ ) when poly-APS (A) or LipoGen (B) concentration was increased, expressed in a mole ratio of ammonium/DNA phosphate (N/P). Both poly-APS (4.I-4.7 $\mu \mathrm{g} / \mathrm{ml}$ ) and LipoGen $(3.3-5.5 \mu \mathrm{g} / \mathrm{ml})$ condense DNA efficiently with $10 \%$ residual fluorescence at N/P ratios $3.5-4.0$ and $(\mathrm{N} /$ P) $1.5-2.5$ respectively, $(n=3$ for all experiments, error bars represent standard deviation). Light scattering confirmed that cationic vector-DNA complexes were formed, (C) for poly-APS, (D) for LipoGen, as the apparent absorbance at $320 \mathrm{~nm}$ increases significantly from the DNA only control solution.

ratios for DNA condensation for poly-APS and LipoGen were at $3.50-4.00(4.1-4.7 \mu \mathrm{g} / \mathrm{ml})$ and $1.50-2.50(3.3-$ $5.5 \mu \mathrm{g} / \mathrm{ml}$ ). All three DNA samples used in our study were condensed in the same manner by each compound. Interestingly, fluorescence intensity from LipoGen-mediated DNA condensation experiment decreased much more sharply than with poly-APS. This superior DNA condensation effect could be associated with the positive charge distribution/number and lipophilicity of LipoGen over poly-APS.

\section{Poration of cell membranes by poly-APS}

The measurement of increases in intracellular $\mathrm{Ca}^{2+}$ with fura- 2 can be used as an index of $\mathrm{Ca}^{2+}$ entry through channels resulting from the interactions of pore forming molecules with cell membranes [1-3]. Ratiometric intracellular $\mathrm{Ca}^{2+}$ imaging was conducted to compare pore formation or permeabilisation of cell membranes by poly-APS, LipoGen and lipofectamine. Poly-APS $(1 \mu \mathrm{g} /$ $\mathrm{ml}$ ) evoked transient increases in intracellular $\mathrm{Ca}^{2+}$ in HEK 293 cells at room temperature $\left(21^{\circ} \mathrm{C}\right)$. In contrast Lipo- 


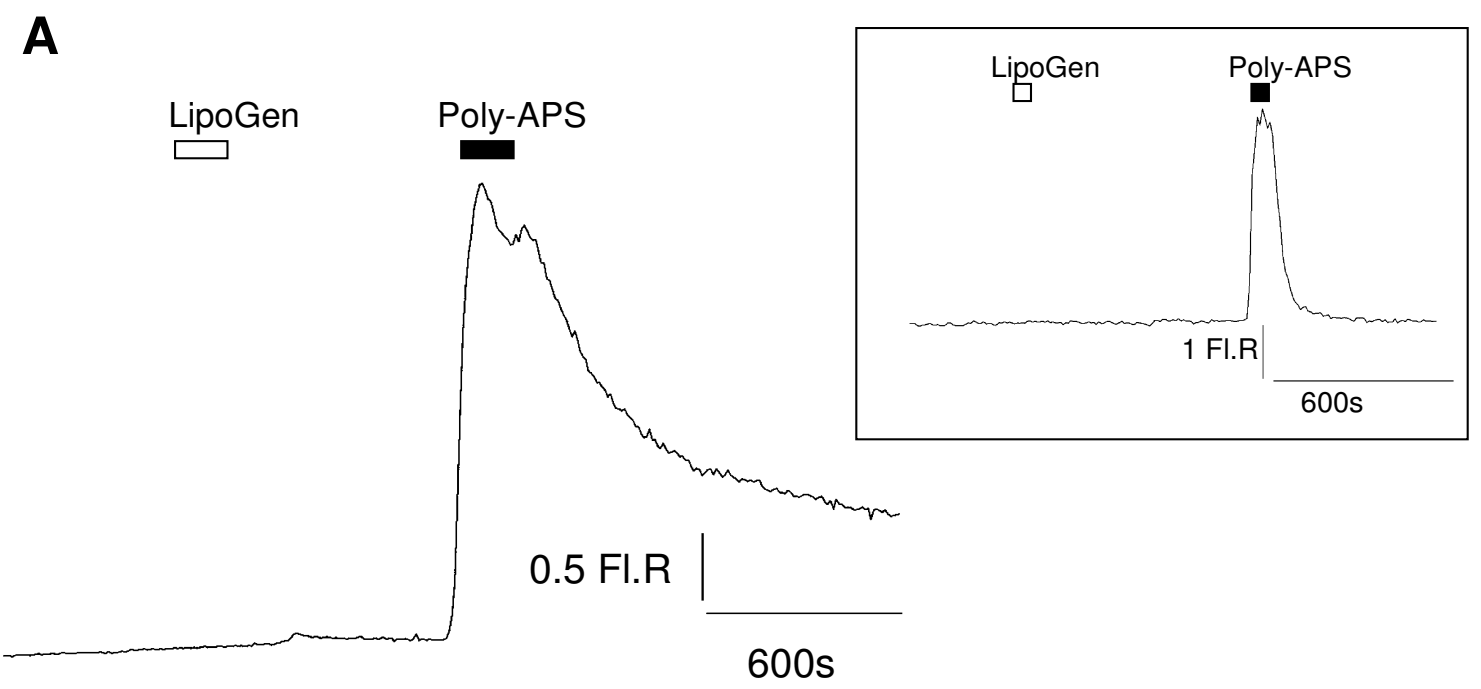

B
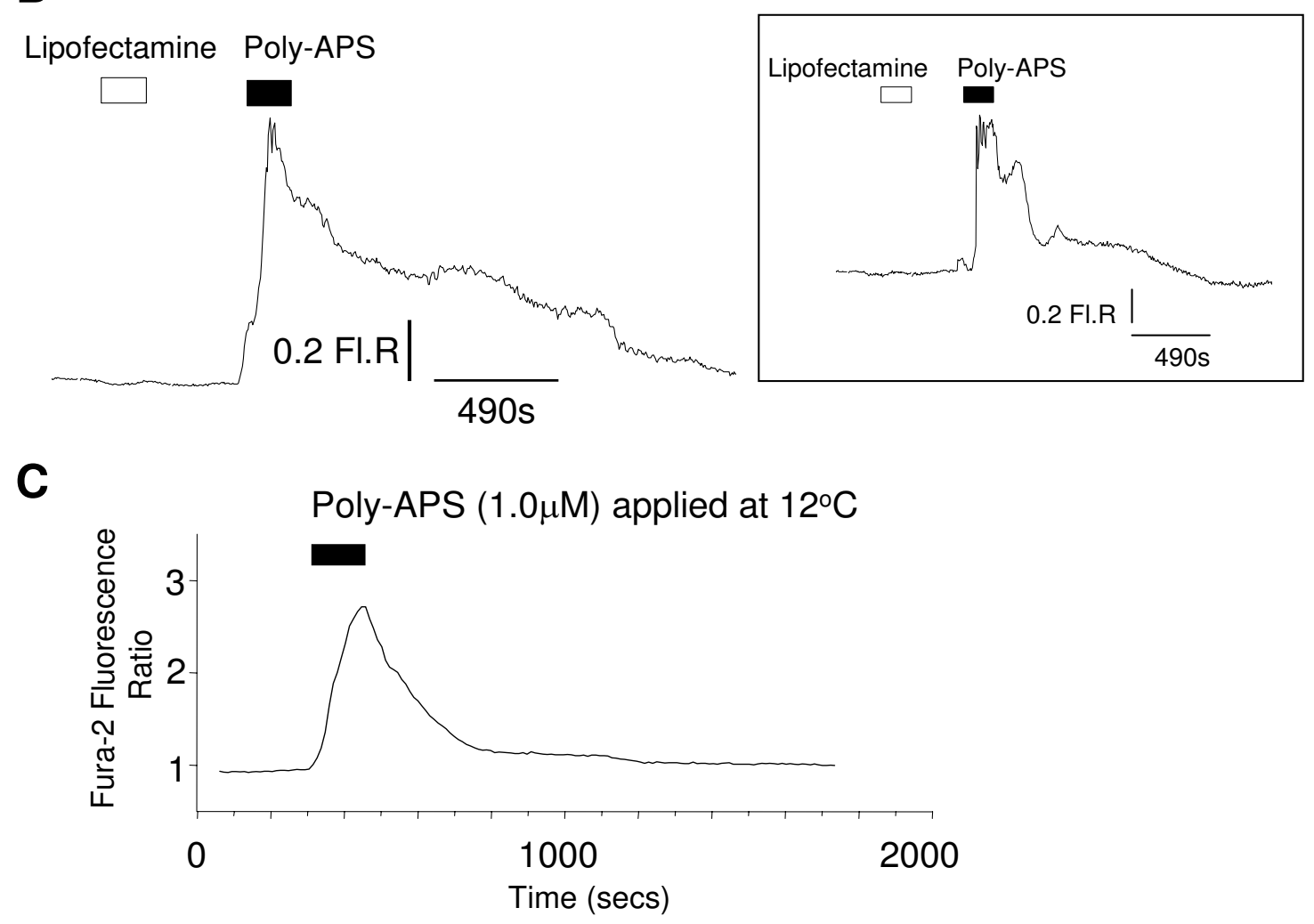

\section{Figure 3}

Records of fura-2 $\mathrm{Ca}^{2+}$ imaging. A, average (mean; $\mathrm{n}=30 \mathrm{HEK} 293$ cells) trace showing that LipoGen (I $\left.\mu \mathrm{g} / \mathrm{ml}\right) \mathrm{failed}$ to cause a rise in intracellular $\mathrm{Ca}^{2+}$ but that polymeric alkylpyridinium salt (Poly-APS; I $\mu \mathrm{g} / \mathrm{ml}$ ) increased intracellular Ca ${ }^{2+}$ measured as a change in fluorescence ratio (FI.R). The rise in intracellular $\mathrm{Ca}^{2+}$ was indicative of pore formation. Inset record shows a trace of changes in intracellular $\mathrm{Ca}^{2+}$ from a single cell. $\mathrm{B}$, average (mean; $\mathrm{n}=19 \mathrm{HEK} 293$ cells) trace showing that lipofectamine (I $\mu$ g/ $\mathrm{ml}$ ) failed to cause a rise in intracellular $\mathrm{Ca}^{2+}$ but that polymeric alkylpyridinium salt (Poly-APS; I $\mu \mathrm{g} / \mathrm{ml}$ ) increased intracellular $\mathrm{Ca}^{2+}$, indicative of pore formation. Inset record shows a trace of changes in intracellular $\mathrm{Ca}^{2+}$ from a single cell. $\mathrm{C}$, single cell trace of a $\mathrm{Ca}^{2+}$ transient evoked at $12^{\circ} \mathrm{C}$ by poly-APS. 
A

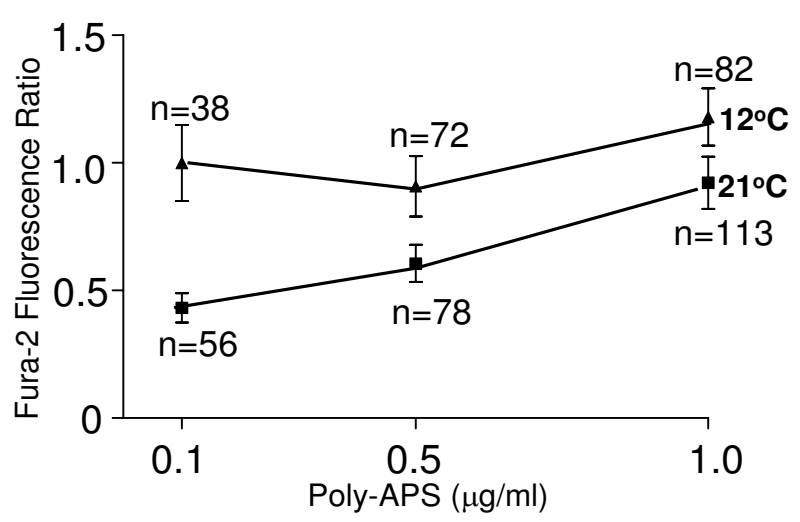

B

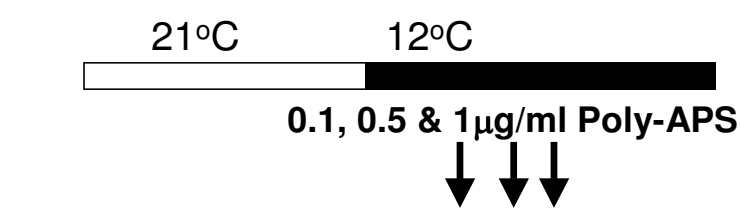

$0.1,0.5 \& 1 \mu \mathrm{g} / \mathrm{ml}$ Poly-APS

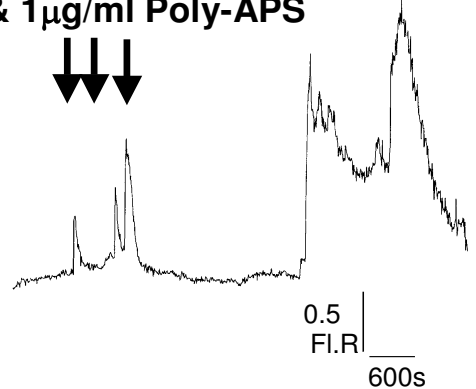

\section{Figure 4}

Temperature sensitivity of poly-APS actions. A, dose/ response relationship for poly-APS-evoked $\mathrm{Ca}^{2+}$ transients at room temperature $\left(21^{\circ} \mathrm{C}\right.$, filled squares) and at $12^{\circ} \mathrm{C}$ (filled triangles). At each concentration of poly-APS, larger responses were obtained at the lower temperature. The different $n$ values reflect variable sensitivities of HEK 293 cells to poly-APS with cells being more sensitive at lower temperatures. B, an example record showing larger increases in intracellular $\mathrm{Ca}^{2+}$ (FI.R Fluorescence Ratio units) in response to poly-APS at $12^{\circ} \mathrm{C}$ compared with $21^{\circ} \mathrm{C}$.

Gen $(1 \mu \mathrm{g} / \mathrm{ml})$ and lipofectamine $(1 \mu \mathrm{g} / \mathrm{ml})$ both failed to evoke any changes in intracellular $\mathrm{Ca}^{2+}$ indicating that acute application of these compounds at this concentration did not result in pore formation in cell membranes and an increase in $\mathrm{Ca}^{2+}$ permeability (Figure 3A,B). PolyAPS also efficiently evoked $\mathrm{Ca}^{2+}$ transients at $12^{\circ} \mathrm{C}$ (Figure 3C).

Dose/response relationships for poly-APS-evoked intracellular $\mathrm{Ca}^{2+}$ transients were generated at $12^{\circ} \mathrm{C}$ and at room temperature $\left(21^{\circ} \mathrm{C}\right)$. At $21^{\circ} \mathrm{C}$ a clear dose-depend- ent relationship was obtained with $1.0 \mu \mathrm{g} / \mathrm{ml}$ poly-APS giving significantly larger responses than $0.1 \mu \mathrm{g} / \mathrm{ml}$ polyAPS $(\mathrm{P}<0.005, \mathrm{n}=113 \& 56)$. In contrast at $12^{\circ} \mathrm{C}$ no clear dose-dependent relationship was observed with the mean responses to 1.0 and $0.1 \mu \mathrm{g} / \mathrm{ml}$ poly-APS not being significantly different. This can be explained by the significantly larger $\mathrm{Ca}^{2+}$ transients evoked by $0.1 \mu \mathrm{g} / \mathrm{ml}$ poly-APS at $12^{\circ} \mathrm{C}$. At $12^{\circ} \mathrm{C}$ the peak $\mathrm{Ca}^{2+}$ transient had a mean amplitude of $1.0 \pm 0.15$ fluorescent ratio units $(\mathrm{n}=38)$, at $21^{\circ} \mathrm{C}$ the same concentration of poly-APS evoked a significantly smaller response of $0.43 \pm 0.06$ fluorescent ratio units ( $\mathrm{n}$ $=56 ; \mathrm{P}<0.001$; Figure $4 \mathrm{~A}, \mathrm{~B})$. This effect of temperature became less apparent at higher concentrations of polyAPS. At $1.0 \mu \mathrm{g} / \mathrm{ml}$ poly-APS there was no significant difference between responses obtained at $12{ }^{\circ} \mathrm{C}$ and $21^{\circ} \mathrm{C}$ (Figure $4 \mathrm{~A}$ ). Therefore there was an apparent 10 -fold shift in sensitivity to poly-APS with a $9^{\circ} \mathrm{C}$ drop in temperature. The increase in sensitivity of HEK 293 cells to poly-APS at low temperature was also apparent because a few cells failed to respond at all to poly-APS applied at $21^{\circ} \mathrm{C}$ but subsequently responded well to poly-APS when the temperature was reduced to $12^{\circ} \mathrm{C}$. The majority of experiments were conducted by applying poly-APS at room temperature and then reducing the temperature to $12^{\circ} \mathrm{C}$ and reapplying cooled poly-APS. However, temperature sensitivity was still equally apparent when the experiments were conducted the other way around by firstly applying poly-APS at $12^{\circ} \mathrm{C}$ and then raising the temperature to $21^{\circ} \mathrm{C}$ and reapplying poly-APS. The changes in temperature sensitivity to poly-APS were readily reversible within 5 to $10 \mathrm{~min}$ of a temperature increase or decrease.

\section{Intracellular delivery of lucifer yellow}

Experiments into pore formation were also conducted using lucifer yellow as a probe. Although lucifer yellow has a low molecular weight (457.25 Da) it is a convenient dye to assess changes in membrane integrity. In the absence of poly-APS, no lucifer yellow was found intracellularly, this was irrespective of the incubation periods of 1,2 and $3 \mathrm{~h}$ and temperature, $7^{\circ} \mathrm{C}, 21^{\circ} \mathrm{C}$ and $37^{\circ} \mathrm{C}$. Similarly, no intracellular delivery of lucifer yellow was achieved using poly-APS at an incubation temperature of $37^{\circ} \mathrm{C}$. However, low levels of intracellular delivery of lucifer yellow, was seen with poly-APS at an incubation temperature of $21^{\circ} \mathrm{C}$. We estimate that at $21^{\circ} \mathrm{C}$ intracellular loading with lucifer yellow was seen in about $5 \%$ of HEK 293 cells, but that this loading into individual cells was intense (Figure 5A). In contrast, when incubations were carried out at $7^{\circ} \mathrm{C}$ poly-APS achieved efficient loading of lucifer yellow into at least $90 \%$ of cells (Figure 5B). Furthermore, the loaded lucifer yellow remained in these cells after returning the cells to culture medium and incubating them in standard culture media at $37^{\circ} \mathrm{C}$ for $24 \mathrm{~h}$. In contrast little $\left(21^{\circ} \mathrm{C}\right)$ or no $\left(7^{\circ} \mathrm{C}\right)$ lucifer yellow uptake was observed when HEK 293 cells were incubated with 

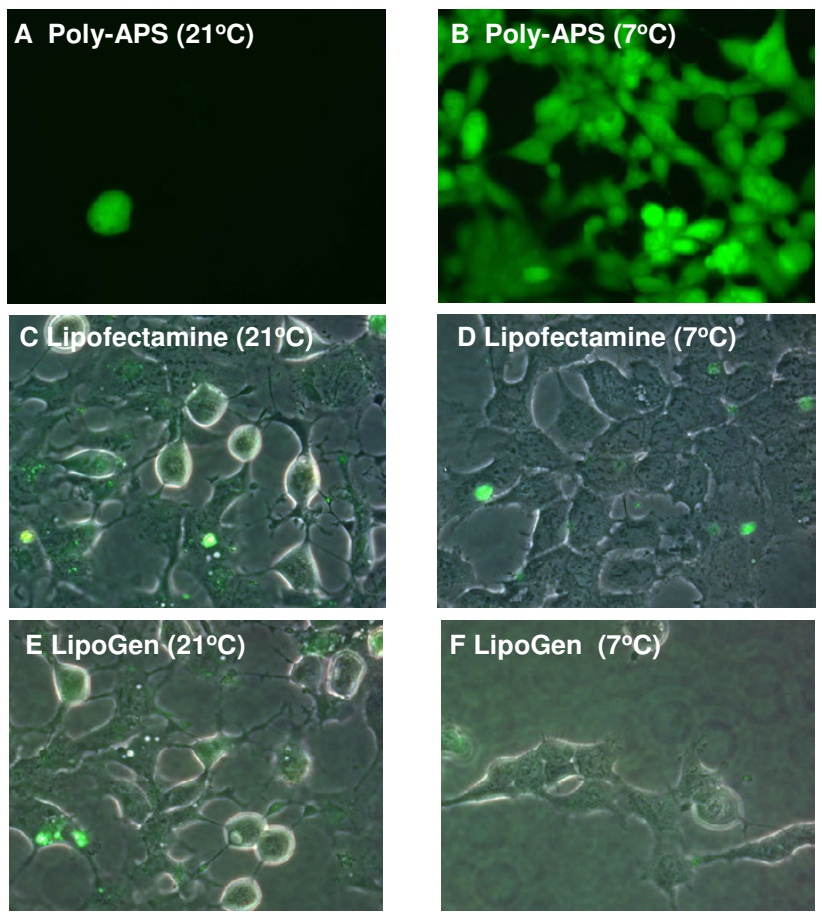

\section{Figure 5}

Temperature effects were also seen when poly-APS was used for intracellular delivery of lucifer yellow. In the absence of poly-APS no intracellular uptake of lucifer yellow was observed over a $3 \mathrm{~h}$ incubation period. After incubation with poly-APS and lucifer yellow (I mM) for $3 \mathrm{~h}$ at $21^{\circ} \mathrm{C}$ a few individual cells were loaded (A), but after incubation at $7^{\circ} \mathrm{C}$ almost all cells are filled with lucifer yellow (B). Lipofectamine and LipoGen did not deliver lucifer yellow efficiently. Merged transmission and fluorescence images show that a very modest amount of fluorescence was observed after incubation with lipofectamine and lucifer yellow $(\mathrm{I} \mathrm{mM})$ for $3 \mathrm{~h}$ at $21^{\circ} \mathrm{C}$ (C) and no cells were loaded at $7^{\circ} \mathrm{C}$ (D). Similarly, with LipoGen, little fluorescence was seen after incubation at $21^{\circ} \mathrm{C}(\mathrm{E})$ and no cells were loaded at $7^{\circ} \mathrm{C}(\mathrm{F})$.

either lipofectamine ( $4 \mu \mathrm{g} / \mathrm{ml}$; Figure $5 \mathrm{C}, \mathrm{D})$ or LipoGen $(4 \mu \mathrm{g} / \mathrm{ml}$; Figure 5E,F).

\section{pEGFP delivery by poly-APS and lipopolyamines}

Given that pore formation in cell membranes could be achieved at $12^{\circ} \mathrm{C}$ with poly-APS, we examined whether lipofectamine, LipoGen and poly-APS would still function as transfection reagents at lower temperatures. For these experiments different incubation protocols were used for lipofection systems and for poly-APS. A standard protocol forming complexes between lipofectamine and DNA and LipoGen and DNA was used but for poly-APS to work poly-APS was applied separately to cells to allow pore formation before adding DNA [2]. Incubation protocols with HEK 293 cells, lipofectamine and poly-APS at $12{ }^{\circ} \mathrm{C}$ still resulted in delivery of cDNA encoding for the expression of enhanced green fluorescent protein and transfection with both reagents (Figure 6A,B). Lipofectamine was less efficient as a transfection reagent at $12^{\circ} \mathrm{C}$ with about $30-50 \%$ of HEK 293 cells transfected compared with $75-80 \%$ transfection at $37^{\circ} \mathrm{C}$. With polyAPS the transfection efficiency was $20-30 \%$ at $12^{\circ} \mathrm{C}$ and therefore similar to that achieved at $37^{\circ} \mathrm{C}$ [2]. Lipofection systems were also assessed at $12^{\circ} \mathrm{C}$ and $37^{\circ} \mathrm{C}$ using the same transfection condition and HtTA HeLa cells. There was a significant decrease of gene expression at $12{ }^{\circ} \mathrm{C}$ (Figure $6 \mathrm{C}$ ), compared to transfection and gene expression at $37^{\circ} \mathrm{C}$ normally used for optimal cell growth. This data suggests that LipoGen and lipofectamine-mediated transfection requires endocytosis, and probably does not work to any great degree through the pore formation mechanism.

\section{Intracellular delivery and function of siRNA}

Given the abilities of poly-APS, lipofectamine and LipoGen to act as transfection reagents for cDNA we were interested to determine whether they would deliver siRNA into HEK 293 cells. For these experiments initial incubation protocols were carried out at $37^{\circ} \mathrm{C}$ because at this temperature transfection with cDNA has been achieved with all three reagents used. The intracellular delivery of siRNA was detected firstly by visualisation of intracellular siRNA labelled with fluorescein and secondly by evaluating knockdown of specific protein expression. Experiments using lipofectamine showed that in the presence of serum substantial knockdown in protein expression was observed after $48 \mathrm{~h}$. In contrast when incubations were carried out in serum-free conditions substantial knockdown could be identified after $24 \mathrm{~h}$ but knockdown did not increase further after $48 \mathrm{~h}$. Therefore in all other experiments serum-free incubation conditions were used and analysis of protein knockdown was carried out after $24 \mathrm{~h}$.

Figures 7A\&B show intracellular fluorescence produced by the fluorescein-labelled siRNA delivered into HEK 293 cells using lipofectamine or LipoGen. No intracellular fluorescence was observed under control conditions, in the absence of any transfection reagent (cells incubated with siRNA alone) or when $1.0 \mu \mathrm{g} / \mathrm{ml}$ poly-APS was used to porate the cell membrane. In the presence of poly-APS intracellular fluorescence of fluorescein-labeled siRNA was not seen even if the siRNA concentration was increased 4-fold. Additional experiments were conducted at a lower temperature to increase poly-APS-mediated pore formation. When incubations were carried out with poly-APS and siRNA conjugated with fluorescein at $12^{\circ} \mathrm{C}$ for $5 \mathrm{~h}$ no intracellular delivery of the siRNA was detected $(n=4)$. The presence or absence of $10 \%$ serum did not influence either the activity of lipofectamine or the inactivity of poly-APS (Figure 8A). The delivery of siRNA specific for $\beta$-actin, using lipofectamine or LipoGen had 

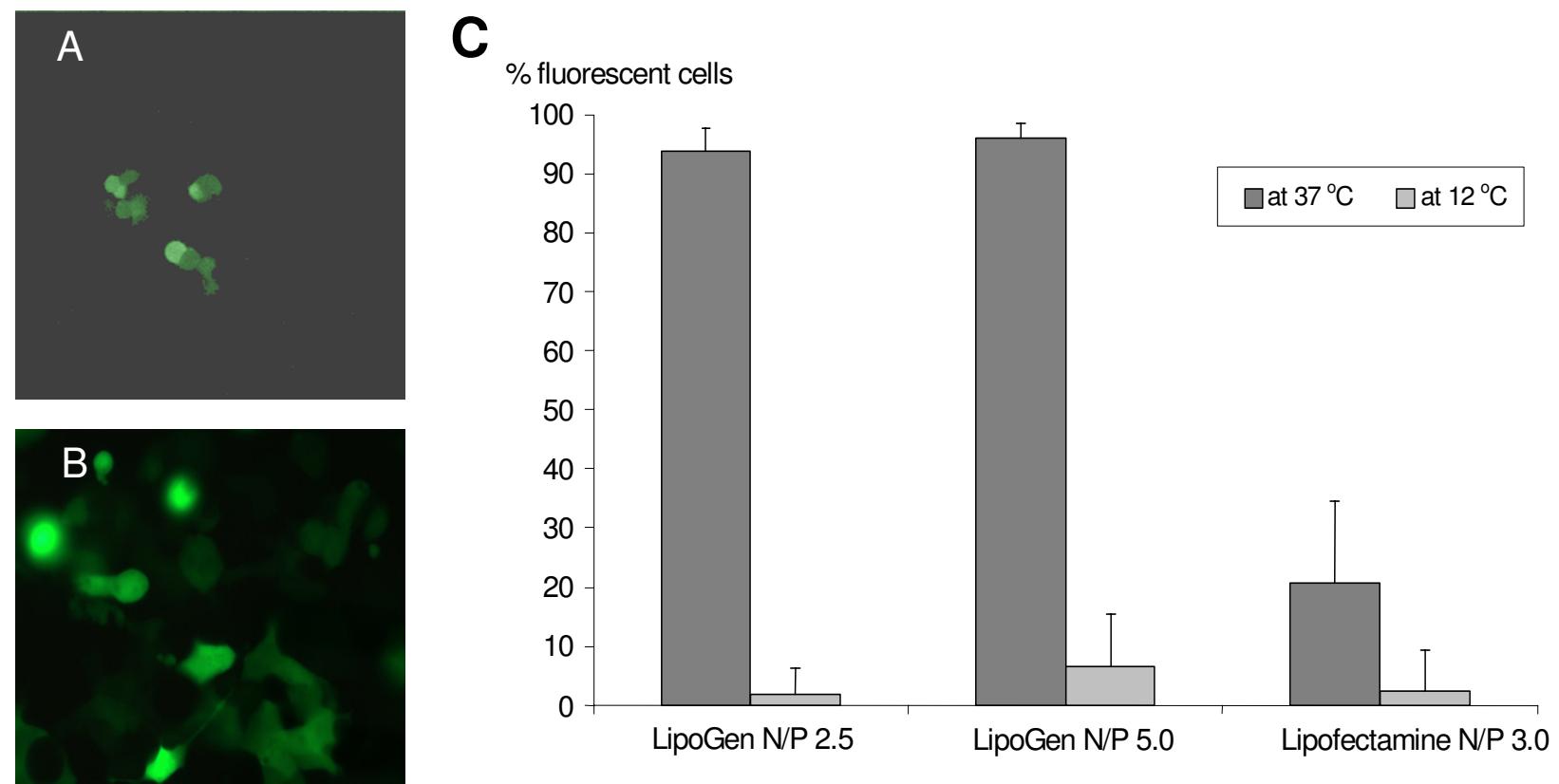

\section{Figure 6}

Effect of temperature on gene delivery. A, confocal image showing expression of enhanced green fluorescent protein in HEK 293 cells after transfection at $12^{\circ} \mathrm{C}$ with poly-APS $(0.5 \mu \mathrm{g} / \mathrm{ml} ; 2.5 \mu \mathrm{g}$ PEGFP). B, fluorescence microscope image showing expression of enhanced green fluorescent protein in HEK 293 cells after transfection at $12^{\circ} \mathrm{C}$ with lipofectamine $(4 \mu g / 200 \mu \mathrm{l}$; I $\mu$ g PEGFP). After incubation at $12^{\circ} \mathrm{C}$ for cDNA delivery, cells were returned to standard culture media and conditions and incubated at $37^{\circ} \mathrm{C}$ for $24 \mathrm{~h}$ before being examined. C, Histogram showing the temperature dependence of gene delivery to HtTA HeLa cells. pEGFP DNA complexed with LipoGen (N/P ratio 2.5 and 5.0) and Lipofectamine (N/P ratio 3.0) were added into each well of HtTA HeLa cells (cervix carcinoma, $50 \%$ confluent) in serum-free media. Transfection experiments were performed at $37^{\circ} \mathrm{C}$ or $12^{\circ} \mathrm{C}$, and then DNA complexes were removed after $4 \mathrm{~h}$ exposure. The number of fluorescent cells was determined by FACS cytometry after $44 \mathrm{~h}$ post-transfection at $37^{\circ} \mathrm{C}$, to determine the efficiency of pEGFP delivery systems. Significant decrease of transfection efficiency at $12^{\circ} \mathrm{C}$ was found in all lipofection systems used, compared with standard transfection conditions at $37^{\circ} \mathrm{C}$. ( $n=3$ for all transfections, three replicates each, error bars represent standard deviation).

functional consequences, knocking down protein expression by $30 \%$ (max knockdown 34 \& $65 \%$ respectively) compared to $\beta$-actin expression in control cells (Figure $8 B, C)$. The levels of $\beta$-actin seen in cells exposed to polyAPS and siRNA specific for $\beta$-actin were comparable with those measured for the controls but significantly $(P$ $<0.005)$ higher than the levels seen after lipofectamine or LipoGen mediated delivery of siRNA (Figure 9).

\section{Discussion}

Poly-APS is a highly efficient DNA condensing agent with an additional property of being able to reversibly form pores in membranes, which are highly desirable characteristics for any non-viral vectors. In addition to cell entry facilitation, this membrane perturbation could also help in endosomal escape process, which is one of key barriers in gene delivery. The structure modification of poly-APS i.e. lipid conjugation, alkyl chain length control and degree of polymerisation, may further improve its DNA condensing, pore formation, transfection efficiency, and toxicity profiles.

Other pyridinium compounds have proved useful transfection reagents, these include the SAINT (synthetic amphiphile INTeraction) series [8], which have high transfection efficiency when used in a liposomal formulation with 1,2-dioleoyl phosphatidylethanolamine (DOPE). The SAINT series are conjugations of two fatty acid chains (tail group) with pyridinium head groups. From structure-activity relationship studies, it was found that unsaturated fatty chains enhanced the transfection efficiency. Head group modification by introducing another pyridinium group linked with an alkyl spacer, also significantly improved the transfection efficiency. Interestingly, C4 spacer (in SAINT-3) linking two pyridinium heads shows the highest efficiency in DNA delivery, compared to C3 and C5 spacers [8]. Lipophilicity and alkyl chain length modifications of poly-APS, leading to 

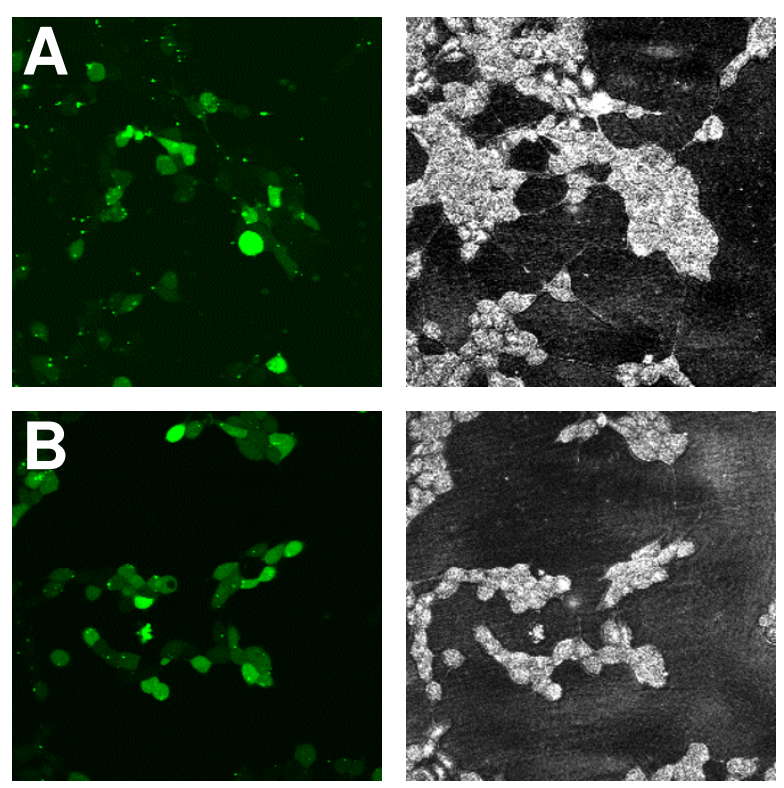

\section{Figure 7}

Delivery of siRNA with lipofectamine and LipoGen into HEK 293 cells. Intracellular delivery of siRNA fluorescein conjugate using $A$, lipofectamine and $B$, LipoGen as transfection reagents was visualised as confocal transmission images after a $4.5 \mathrm{~h}$ incubation period. No siRNA-positive cells were observed in the absence of a transfection reagent or after incubation with poly-APS. The left-hand images are fluorescent images and the right-hand images are corresponding transmission images.

optimal positive charge regiochemical distribution, (distance between pyridinium head-groups in the poly-APS molecules) may in the future improve pore formation and transfection properties of modified poly-APS.

Previously, we have shown that a sponge toxin preparation, poly-APS, can produce pores in cell membranes and perform as a transfection reagent. This is unusual given that poly-APS is a natural product preparation and it raises the possibility that in nature as well as acting in chemical defence, polymeric alkypyridinium compounds may also provide a novel mechanism of natural horizontal genetic material transfer between marine microorganisms. The mechanism by which poly-APS delivers macromolecules into cells and achieves transfection is unknown. However, reversible pore formation by poly-APS and movement of macromolecules down concentration or electrochemical gradients into cells through these structures may provide a novel mechanism for the intracellular delivery of normally impermeant molecules. An alternative mechanism might involve the binding of poly-APS to cDNA, this complex binding to cell membranes and then internalisation by endocytosis. The processes of endocytosis are temperature dependent as temperature affects both rate of ligand binding and mobility of ligand-receptor complexes in membranes. Endocytotic processes are usually blocked at temperatures below $12^{\circ} \mathrm{C}$. For example lucifer yellow uptake into platelets by fluid phase endocytosis occurs above $15^{\circ} \mathrm{C}$ [13]. Although platelets clearly load with lucifer yellow at $37^{\circ} \mathrm{C}$ no such uptake was seen at this temperature in HEK 293 cells. However, dramatic stable intracellular loading of lucifer yellow into HEK 293 cells was facilitated by poly-APS during low temperature incubations. This event was not supported by lipofectamine or LipoGen and must therefore be due to some processes other than fluid phase endocytosis. Experiments were conducted to determine whether poly-APS would permeabilise cells, as reflected by calcium influx, support transfection of cDNA encoding for the expression of enhanced green fluorescent protein and delivery of lucifer yellow into cells at $7-12^{\circ} \mathrm{C}$. At low temperatures, poly-APS functions well, both as a pore former and as a transfection reagent for delivery of cDNA. This indicates that endocytosis is unlikely to be the mechanism by which poly-APS delivers cDNA and lucifer yellow into cells. Additionally, the protocol used for cDNA delivery also suggests that endocytosis is not involved because there is a requirement to incubate cells in poly-APS prior to exposure with cDNA. Furthermore, the temperature data adds to the evidence (pre-mixing poly-APS with cDNA actually prevents transfection), that pore formation by poly-APS is critical for macromolecule delivery. Although lipofectamine and LipoGen could be used as a transfection reagent at $12^{\circ} \mathrm{C}$ they were much less efficient at low temperatures compared to high temperatures. A further difference was the failure of lipofectamine and LipoGen to cause an increase in intracellular $\mathrm{Ca}^{2+}$, therefore these reagents show very different biological activity compared to poly-APS.

The polymeric structure of poly-APS appears critical to at least some of its biological activities. We previously found that two monomeric compounds, cetylpyridinium chloride and cetyltrimethylammonium bromide, did not reversibly permeate cell membranes and did not support transfection [14]. A recent investigation on poly-APS and synthetic linear alkylpyridinium monomers, dimers and tetramers showed that biological activities such as antibacterial, hemolytic activities, anti-acetylcholinesterase activities and inhibition of protein phosphatase $2 \mathrm{~A}$ are greatly and differentially influenced by increasing numbers of positive charges and pyridinium rings. The smaller synthetic compounds showed good anti-enzymatic and antibacterial activity. In contrast poly-APS showed much greater hemolytic activity compared to the smaller synthetic compounds [15]. 


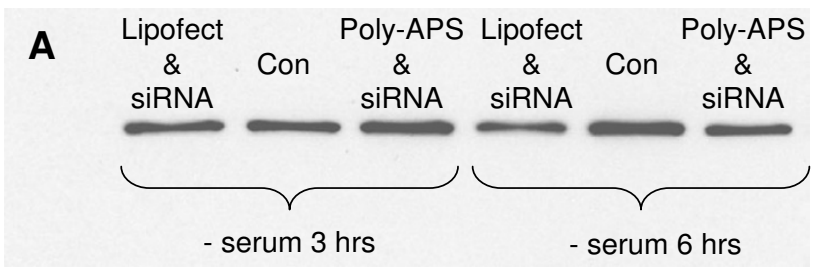

B NFкB p65 standard

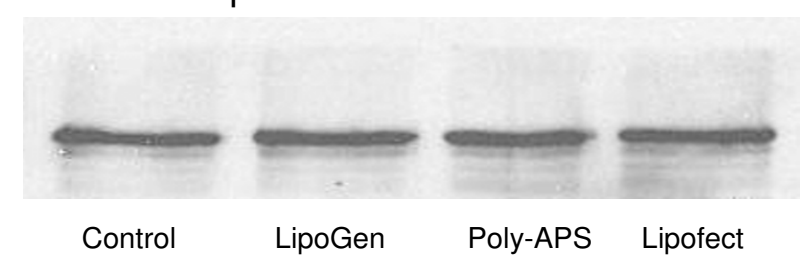

C $\beta$-actin knockdown with siRNA

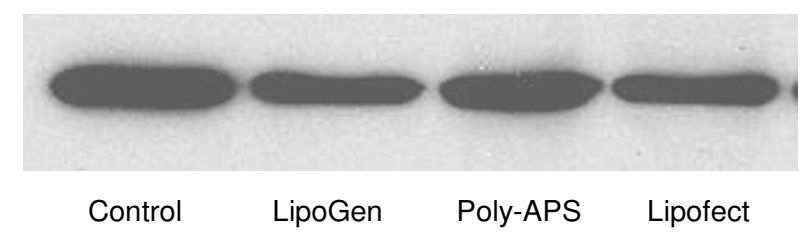

Figure 8

Delivery of $\beta$-actin siRNA using lipofectamine knocked down $\beta$-actin. A, Western blots of $\beta$-actin expression in HEK 293 cells and knockdown by delivery of $\beta$-actin siRNA using lipofectamine (Lipofect), but not poly-APS, in the absence of serum in the incubation media for $3 \mathrm{~h}$ and $6 \mathrm{~h}$. The presence of $10 \%$ serum has been shown to attenuate poly-APS-mediated pore formation, so experiments were conducted in serum-free conditions. $B$, shows a standard loading record for NFKB for the Western blots of siRNA knockdown of $\beta$ actin by LipoGen, poly-APS and lipofectamine (Lipofect) illustrated in part $C$ of this figure. $C$, Western blots for siRNA knockdown of $\beta$-actin by LipoGen, lipofectamine (Lipofect) and poly-APS.

Evidence suggests that a reduction in temperature enhances pore formation by poly-APS both at the lowest concentration of poly-APS tested $(0.1 \mu \mathrm{g} / \mathrm{ml})$ and in cells that were less sensitive and failed to respond to poly-APS at room temperature. It is likely that this effect is due to both temperature-dependent alterations in physicochemical properties of the cell membrane and conformational changes in poly-APS resulting in promotion of poly-APS insertion into the membrane and pore formation. However, poly-APS did not deliver siRNA or knockdown protein, whereas both lipofectamine and LipoGen delivered siRNA and produced specific knockdown of functional $\beta$ actin similarly. It is not clear why siRNA was not delivered into HEK 293 cells.

\section{Conclusion}

In conclusion, poly-APS was found to be an efficient pore former and at low temperatures $\left(7-12^{\circ} \mathrm{C}\right)$ could deliver into cells both cDNA and lucifer yellow but not siRNA. In the future it would be interesting to evaluate the binding of siRNA to poly-APS and its influences on pore formation. It is noteworthy that pyridinium salts are efficient quenching agents reflecting binding properties. Although quenching might have accounted for the negative result obtained when we attempted to deliver fluoresceinlabeled siRNA with poly-APS, it does not explain the negative results with siRNA targeted against $\beta$-actin. In contrast to poly-APS, LipoGen and lipofectamine did not form $\mathrm{Ca}^{2+}$ permeant pores, but did deliver siRNA into cells and are likely to function in a similar manner. Further studies of the temperature sensitivity to poly-APS might provide approaches, using low temperature and low polyAPS concentrations, to improve efficiency and selectively delivery of macromolecules into cells. In the context of the negative temperature coefficient for poly-APS, it is interesting to note that newly discovered 1,3-dialkylpyridinium and related compounds have been extracted from Arctic species of sponges [19-21]. These findings show that alkylpyridinium compounds are not confined to temperate and tropical Haplosclerida but may contribute to host defence in cold environments.

\section{Methods \\ Materials}

Poly-APS $\left(\mathrm{C}_{13} \mathrm{H}_{20} \mathrm{~N}^{+}\right.$monomer M.W. 190.16, [4] with one positive charge per monomer unit) were purified from the Adriatic marine sponge Reniera sarai as previously described [4], and dissolved in MilliQ water (stock solution $1 \mu \mathrm{g} / \mu \mathrm{l}$ ) [1-3]. Poly-APS is readily solubilized in distilled water at room temperature and can be kept for months at $4^{\circ} \mathrm{C}$ without loosing biological activities. We have never observed any precipitation at $4{ }^{\circ} \mathrm{C}$ when polyAPS was kept at concentrations up to $1.5 \mathrm{mg} / \mathrm{ml}$. However, the solubility is highly dependant on the polarity of the solvent and poly-APS is only poorly soluble in methanol, and even less soluble in ethanol. There is only very limited data on phase behaviour of poly-APS in water. Experiments with dynamic and static light scattering [4] have shown that poly-APS exists as a mixture of monomolecular polymers, creating large supramolecular spherical aggregates with a hydrodynamic radius of $23 \mathrm{~nm}$.

$N^{4}, N^{9}$-dioleoylspermine (LipoGen) [5,7] was synthesized by the procedure described elsewhere [16]. LipoGen was dissolved in ethyl alcohol (stock solution $2 \mu \mathrm{g} / \mu \mathrm{l}$ ). Buffers and $\mathrm{NaCl}$ solution were also made up in MilliQ water and buffers were adjusted to 7.4 with aq. $\mathrm{NaOH}$ solution.

Lipofectamine was purchased from Invitrogen, U.K. pEGFP (4.7 kbp) and pGL3 (5.3 kbp) DNA were prepared 


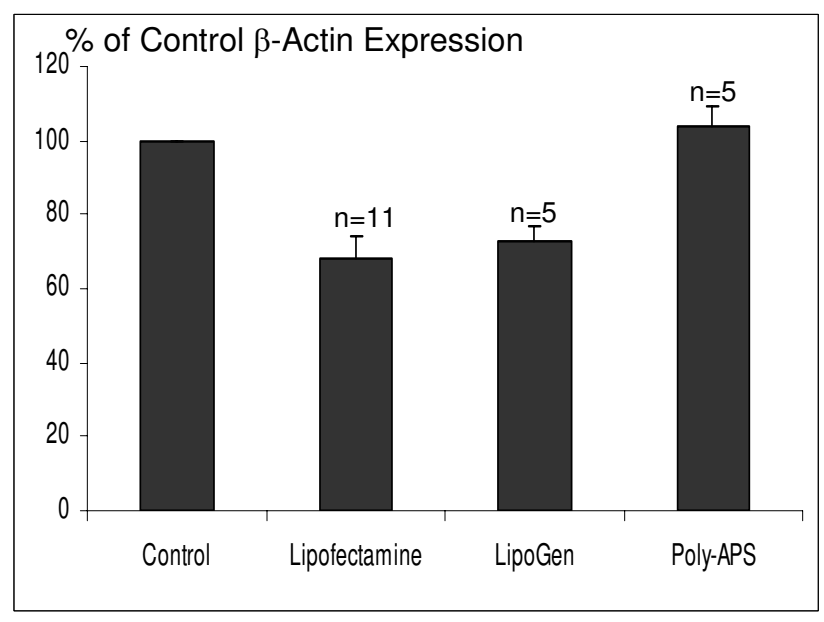

\section{Figure 9}

Histogram showing normalised data for siRNA knockdown of $\beta$-actin and the effect of different transfection reagents. All data are represented as mean percentage expression relative to the control. Data analyses conducted after 24 or $48 \mathrm{~h}$ are included.

according to the Maxiprep plasmid amplification and purification protocol and stored in a freezer before use. Calf thymus DNA was purchased from Sigma-Aldrich U.K. Foetal calf serum (FCS), $10 \times$ Minimum essential media (MEM), Penicillin G, Streptomycin, L-glutamine, $7.5 \% \mathrm{NaHCO}_{3}$, trypsin, PBS, and serum-free MEM (OptiMEM) were obtained from Gibco-Invitrogen.10\% Media used during transfection complexes addition was either $\mathrm{NaCl}$-based saline or serum-free MEM. Other chemicals used were supplied from Sigma-Aldrich U.K.

\section{DNA condensation}

The displacement assay fluorescence measurements were run with Perkin-Elmer Fluorescence Spectrophotometer Model LS50B $\left(\lambda_{\text {ex }}=260 \mathrm{~nm}, \lambda_{\text {em }}=600 \mathrm{~nm}, 1 \mathrm{~cm}\right.$ pathlength, $3 \mathrm{ml}$ glass cuvette, slit width $5 \mathrm{~nm}$ ) with FLWinLab version 2.00 for data processing. DNA concentration and purity were carried out with a Helios UV spectrophotometer at $260 \mathrm{~nm}$ (for DNA concentration) and $280 \mathrm{~nm}$ (for protein concentration) prior to the experiments [20]. DNA $(6 \mu \mathrm{g})$ was obtained from the stock solution and diluted to $3 \mathrm{ml}$ with low-NaCl HEPES buffer $(2 \mathrm{mM}$ HEPES, $20 \mathrm{mM} \mathrm{NaCl}, 10 \mu \mathrm{M}$ EDTA, pH 7.4) in a glass cuvette stirred with a micro-flea. Immediately prior to analysis, EthBr solution ( $3 \mu \mathrm{l}, 0.5 \mu \mathrm{g} / \mu \mathrm{l})$ was added to the DNA solution, stirred for 1 min to equilibrate the binding process. Aliquots of poly-APS or LipoGen were added to the stirring DNA solution at the desired ammonium/ phosphate $(\mathrm{N} / \mathrm{P})$ ratio and the fluorescence measured after 1 min equilibration [20,21]. Optimal N/P ratios for DNA condensation for poly-APS and LipoGen were at
3.50-4.00 (4.1-4.7 $\mu \mathrm{g} / \mathrm{ml})$ and $1.50-2.50(3.3-5.5 \mu \mathrm{g} /$ $\mathrm{ml}$ ). The emission intensity was reported as the percentage of maximum fluorescence (100\%) when DNA was fully intercalated by EthBr without the DNA binding agents and corrected for the background fluorescence of total EthBr in buffer solution.

For the light scattering assay, DNA (60 $\mu \mathrm{g})$ was taken from the DNA stock solution and diluted to $3 \mathrm{ml}$ with HEPES buffer ( 2 mM HEPES, 20 mM NaCl, $10 \mu \mathrm{M}$ EDTA, pH 7.4) in a glass cuvette stirred with a micro-flea. Aliquots of poly-APS or LipoGen were added to the stirring DNA solution at the desired N/P ratio and the UV absorbance at 320 $\mathrm{nm}$ was then measured after I min equilibration [21].

\section{HEK 293 cell cultures}

HEK 293 cells (human embryonic kidney cell line) were maintained in culture in Dulbecco's modified Eagle's minimum essential medium, supplemented with $10 \%$ foetal calf serum, $2 \mathrm{mM}$ L-glutamine, $50 \mu \mathrm{U} / \mathrm{ml}$ penicillin, $50 \mu \mathrm{g} / \mathrm{ml}$ streptomycin and $1 \%$ non-essential amino acids. In preparation for experiments and $24 \mathrm{~h}$ prior to experimentation, cells were seeded at a density of 0.5 million cells per $35 \mathrm{~mm}$ dish.

\section{HtTA HeLa cell cultures}

HtTA- 1 HeLa cells, at $1 \times 10^{6}$ cells, were grown in $150 \mathrm{ml}$ flask with $25 \mathrm{ml}$ of 10\% FCS EMEM (minimum essential media with penicillin, streptomycin, glutamine, sodium bicarbonate, and $10 \%$ foetal calf serum) [22-24]. Each $500 \mathrm{ml}$ of media contained $50 \mathrm{ml}$ EMEM $(10 \times), 13.5 \mathrm{ml}$ $\mathrm{NaHCO}_{3}(7.5 \%), 5 \mathrm{ml}$ L-glutamine (200 mM), $25000 \mathrm{IU}$ penicillin $G, 25000 \mu \mathrm{g}$ streptomycin and $10 \%$ foetal calf serum. The culture was incubated at $37^{\circ} \mathrm{C}, 5 \% \mathrm{CO}_{2}$. The cells were passaged every 3 days. Trypsinized cells were added to the next passage at $1 \times 10^{6}$ cells/flask.

\section{$\mathrm{Ca}^{2+}$ imaging}

$\mathrm{Ca}^{2+}$ imaging experiments were conducted at room temperature (approximately $21^{\circ} \mathrm{C}$ ) or $12^{\circ} \mathrm{C}$. HEK 293 cells were bathed in a NaCl-based extracellular solution containing in $\mathrm{mM}: \mathrm{NaCl}, 130 ; \mathrm{KCl}, 3.0 ; \mathrm{CaCl}_{2}, 2.0 ; \mathrm{MgCl}_{2}$, 0.6; $\mathrm{NaHCO}_{3}$ 1.0, HEPES 10.0, glucose 5.0. The $\mathrm{pH}$ and osmolarity of extracellular solutions were adjusted to 7.4 and 310-320 mOsmol/l with $\mathrm{NaOH}$ and sucrose respectively.

Cultured HEK 293 cells were incubated for $1 \mathrm{~h}$ in $\mathrm{NaCl}-$ based extracellular solution containing $10 \mu \mathrm{M}$ fura-2AM (Sigma, $1 \mathrm{mM}$ stock in dimethylformamide) and the effects of poly-APS, lipofectamine and LipoGen on intracellular $\mathrm{Ca}^{2+}$ were evaluated using fluorescence ratiometric imaging as previously described [1-3]. For some experiments, the temperature was changed by perfusing cells with saline at $21^{\circ} \mathrm{C}$ and $12^{\circ} \mathrm{C}$. The temperature was mon- 
itored using a thermometer probe (Jenway 2000 series) placed in the bath containing the cells. All data are given as mean \pm standard error of the mean and statistical significance was determined using the Student's two-tailed unpaired $t$ test.

\section{Macromolecule and probe delivery protocols CDNA delivery into HEK293 cells}

HEK 293 cells were washed with $\mathrm{NaCl}$-based saline or serum-free medium, then exposed to $0.5 \mu \mathrm{g} / \mathrm{ml}$ poly-APS for $5 \mathrm{~min}$ and then poly-APS and $2.5 \mu \mathrm{g} / \mathrm{ml} \mathrm{cDNA}$ encoding for the expression of enhanced green fluorescent protein (pEGFP; Clontech) for $3 \mathrm{~h}$ at $12^{\circ} \mathrm{C}$.

Additionally, experiments were conducted using lipofectamine as the transfection reagent. Lipofectamine (4 $\mu \mathrm{g})$ was mixed with $100 \mu \mathrm{l}$ of serum-free medium and incubated at room temperature for $5 \mathrm{~min}$ prior to adding to $100 \mu \mathrm{l}$ of serum-free medium containing cDNA $(1 \mu \mathrm{g} /$ $\mathrm{ml} ; \mathrm{N} / \mathrm{P}$ ratio 4). After mixing this solution containing transfection reagent and cDNA was incubated for $20 \mathrm{~min}$ at room temperature and then added to the cells. The cells were incubated for $3 \mathrm{~h}$ at $12^{\circ} \mathrm{C}$. After incubation with the transfection reagent and cDNA, serum (to give $10 \%$ ) was added. For cells incubated with $\mathrm{NaCl}$-based saline, serumcontaining medium was added to replace the saline. Cells were maintained in culture for $24 \mathrm{~h}$ before green fluorescent protein was examined using either fluorescence microscopy or confocal imaging.

\section{cDNA delivery into HtTA cells}

DNA complex solution for each well was prepared from solution A and solution B. For solution A, pEGFP $(2 \mu \mathrm{g})$ was diluted to $100 \mu \mathrm{l}$ solution with Opti-MEM medium (serum-free media). Solution B was prepared from LipoGen (5.5 and $11.0 \mu \mathrm{g}$ for N/P ratios of 2.5 and 5.0 respectively), or lipofectamine $(2.53 \mu \mathrm{l}$ for an $\mathrm{N} / \mathrm{P}$ ratio of 3.0$)$ was diluted to $100 \mu \mathrm{l}$ with Opti-MEM medium. Each solution was left at $20^{\circ} \mathrm{C}$ for $30 \mathrm{~min}$. Solutions A and B were then mixed together and vortexed for a brief period, incubated at $20^{\circ} \mathrm{C}$ for 20 min for DNA complexing. In 6-well or 12-well tissue culture plates, HtTA $2.5 \times 10^{4}$ cells/ ml were seeded in $4 \mathrm{ml}$ and $2 \mathrm{ml}$ of $10 \%$ FCS EMEM respectively. The cells were incubated at $37^{\circ} \mathrm{C}$ with $5 \% \mathrm{CO}_{2}$ in an incubator for $24 \mathrm{~h}$, until the cells were $30-50 \%$ confluent. Prior to the addition transfection complexes, media was removed and replaced with either NaCl-based saline or Opti-MEM. NaCl-based extracellular solution used in HtTA cell experiments was the same as used in HEK 293 cell experiments. For $12^{\circ} \mathrm{C}$ experiments, cells were placed in a temperature-controlled refrigerator for 10 min before the transfection. Solutions of DNA complexes ( $200 \mu \mathrm{l} /$ well) were added, and then cells were incubated in either $37^{\circ} \mathrm{C}$ with $5 \% \mathrm{CO}_{2}$ or at $12^{\circ} \mathrm{C}$. The $48 \mathrm{~h}$ post- transfection samples was analysed by FACS for enhanced green fluorescent protein level.

\section{Lucifer yellow delivery}

HEK 293 cells were washed with NaCl-based saline, then exposed to $0.5 \mu \mathrm{g} / \mathrm{ml}$ poly-APS for $5 \mathrm{~min}$ and then polyAPS and $1 \mathrm{mM}$ lucifer yellow (Sigma) for 1, 2 and $3 \mathrm{~h}$. Preincubations in poly-APS and incubations in lucifer yellow were carried at $7{ }^{\circ} \mathrm{C}, 21^{\circ} \mathrm{C}$ and $37^{\circ} \mathrm{C}$. Cells were washed three times before intracellular loading with lucifer yellow was evaluated by fluorescence microscopy immediately after incubation and again after being placed in culture medium and cultured for a further $24 \mathrm{~h}$. Additionally, the abilities of lipofectamine $(4 \mu \mathrm{g} / \mathrm{ml})$ and LipoGen $(4 \mu \mathrm{g} /$ $\mathrm{ml}$ ) to load HEK 293 cells with lucifer yellow were determined over $3 \mathrm{~h}$ incubation periods at $7{ }^{\circ} \mathrm{C}$ and $21^{\circ} \mathrm{C}$.

\section{siRNA delivery}

HEK 293 cells were washed with serum-free medium, then exposed to $1.0 \mu \mathrm{g} / \mathrm{ml}$ poly-APS for $5 \mathrm{~min}$ and then poly-APS and $200 \mathrm{nM}$ siRNA conjugated with fluorescein (QIAGEN) for 4 to $6 \mathrm{~h}$ at $37^{\circ} \mathrm{C}$. An additional set of experiments were carried out with $1.0 \mu \mathrm{g} / \mathrm{ml}$ poly-APS and 200 $\mathrm{nM}$ siRNA conjugated with fluorescein (QIAGEN) for $5 \mathrm{~h}$ at $12^{\circ} \mathrm{C}$. The fluorescence within the cells was assessed immediately after incubation using confocal imaging. Additionally, experiments were conducted using lipofectamine and LipoGen as transfection reagents. Lipofectamine $(4 \mu \mathrm{g})$ or LipoGen $(4 \mu \mathrm{g})$ were mixed with 100 $\mu \mathrm{l}$ of serum-free medium and incubated at room temperature for $5 \mathrm{~min}$ prior to adding to $100 \mu \mathrm{l}$ of serum-free medium containing $50 \mathrm{nM}$ siRNA conjugated with fluorescein. After mixing, this solution containing transfection reagent and siRNA was incubated for $20 \mathrm{~min}$ at room temperature and then added to the cells bathed in $1 \mathrm{ml}$ serumfree medium (final volume $1.2 \mathrm{ml}$ ). The cells were incubated for $4-6 \mathrm{~h}$ at $37^{\circ} \mathrm{C}$ before imaging siRNA intracellular delivery.

Knockdown of $\beta$-actin protein with $\beta$-actin specific siRNA (Ambion) was assessed using Western blot analysis. HEK 293 cells were treated and incubated with transfection reagents (poly-APS, lipofectamine or LipoGen) as above with $100 \mathrm{nM}$ siRNA for lipofectamine and LipoGen or with $333 \mu \mathrm{M}$ siRNA for poly-APS (ratio $1 \mu \mathrm{g}$ : $30 \mathrm{pmol}$ siRNA for lipofectamine and LipoGen and $1 \mu \mathrm{g}$ : 667 pmol siRNA for poly-APS) for 3 or $6 \mathrm{~h}$ at $37^{\circ} \mathrm{C}$. The $\mathrm{N} / \mathrm{P}$ values for the siRNA $\beta$-actin experiments were approximately 1.3 to 8.8 and 1.6 to 10.8 ( 2.4 to $0.35 \mu \mathrm{g} / \mathrm{ml}$ siRNA to $4 \mu \mathrm{g} / \mathrm{ml}$ lipofectamine or LipoGen respectively). Serum was then added (to give a final concentration of $10 \%$ ) and then the cells were maintained in culture for 24 or $48 \mathrm{~h}$. siRNA negative controls were run with non-homologous siRNA. Cells were placed on ice and processed for Western blot protein analysis (Santa Cruz Biotechnology Inc.). Loading 
controls were conducted by stripping the blot and reprobing using antibodies for NFKB (Cell Signalling).

\section{Abbreviations \\ pEGFP plasmid encoding for enhanced green fluorescent protein}

EthBr ethidium bromide

LipoGen $N^{4}, N^{9}$-dioleoylspermine

NVGT non-viral gene therapy

Poly-APS polyalkylpyridinium salts

SAINT Synthetic Amphiphile INTeraction

siRNA small interfering RNA

\section{Competing interests}

The author(s) declare that they have no competing interests.

\section{Acknowledgements}

The authors would like to thank Professor Andy Porter, Dr Frank GunnMoore and Dr Juliette Snow for useful discussion. We thank Dr Bettina Platt, Dr Brian Reid, Mr Carlos Lafourcade, Mr David Koss, Ms Kathleen Hindley and Professor Graeme Nixon for help with the imaging. We also thank Mr Zhiang Zhou for help with the techniques for molecular biology and Mrs Irene Hunter and Ms Jin Pu for a preparation of HEK 293 cells. The authors are grateful to Scottish Enterprise for support under the Knowledge Transfer grants scheme. We thank Universities UK for an ORS award to Noppadon Adjimatera.

\section{References}

I. McClelland D, Evans RM, Abidin I, Sharma S, Choudhry FZ, Jaspars M, Sepčić K, Scott RH: Irreversible and reversible pore formation by polymeric alkylpyridinium salts (Poly-APS) from the sponge Reniera sarai. Br J Pharmacol 2003, I39:| 399-1 408.

2. Tucker S, McClelland D, Jaspars M, Sepčić K, MacEwan D, Scott RH: The influence of alkyl pyridinium sponge toxins on membrane properties, cytotoxicity, transfection and protein expression in mammalian cells. Biochim Biophys Acta 2003, 1614:17|-181.

3. Scott RH, Whyment AD, Foster A, Gordon KH, Milne BF, Jaspars M: Analysis of the structure and electrophysiological actions of halitoxins: I,3 alkyl-pyrdinium salts from Callyspongia ridleyi. J Mem Biol 2000, 176: I 19-I3I.

4. Sepčić K, Guella G, Mancini I, Pietra F, Dalla Serra M, Menestrina G, Tubbs K, Macek P, Turk T: Characterization of anticholinesterase-active 3-alkylpyridinium polymers from the marine sponge Reniera sarai in aqueous solutions. J Nat Prod 1997, 60:991-996.

5. Adjimatera N, Neal AP, Blagbrough IS: Fluorescence techniques in non-viral gene therapy. In Fluorescence spectroscopy in biology: Advanced methods and their applications to membranes, proteins, DNA, and cells Volume 3. Edited by: Hof M, Hutterer R, Fidler V. Springer; 2005:20I-228. [Springer Series on Fluorescence]

6. Blagbrough IS, Geall AJ, Neal AP: Polyamines and novel polyamine conjugates interact with DNA in ways that can be exploited in non-viral gene therapy. Biochem Soc Trans 2003, 3I:397-406.

7. Ronsin G, Perrin C, Guedat P, Kremer A, Camilleri P, Kirby AJ: Novel spermine-based cationic gemini surfactants for gene delivery. Chem Commun 200I, 200 I :2234-2235.
8. Van Der Woude I, Wagenaar A, Meekel AAP, Ter Beest MBA, Ruiters $M H$, Engberts JBFN, Hoekstra D: Novel pyridinium surfactants for efficient, nontoxic in vitro gene delivery. Proc Natl Acad Sci USA 1997, 94: II60-II65.

9. Geall AJ, Blagbrough IS: Rapid and sensitive ethidium bromide fluorescence quenching assay of polyamine conjugate-DNA interactions for the analysis of lipoplex formation in gene therapy. J Pharm Biomed Anal 2000, 22:849-859.

10. Delcros JG, Sturkenboom MC, Basu HS, Shafer RH, Szollosi J, Feuerstein BG, Marton LJ: Differential effects of spermine and its analogues on the structures of polynucleotides complexed with ethidium bromide. Biochem J 1993, 29 I:269-274.

II. Gershon H, Ghirlando R, Guttman SB, Minsky A: Mode of formation and structural features of DNA cationic liposome complexes used for transfection. Biochem 1993, 32:7143-7I5I.

12. Wilson RW, Bloomfield VA: Counterion-induced condensation of deoxyribonucleic acid. a light-scattering study. Biochem 1979, 18:2192-2196.

13. Wolkers WF, Looper SA, Fontanilla RA, Tsvetkova NM, Tablin F, Crowe JH: Temperature dependence of fluid phase endocytosis coincides with membrane properties of pig platelets. Biochim Biophys Acta 2003, 16 I 2:154-163.

14. Scott RH, Tucker SJ, Evans RM, MacEwan DJ, Jaspars M, Sepčić K: Cell membrane permeabilisation by alkylpyridinium sponge toxin preparations and their utilisation as novel transfection reagents. In Neurotox' 2003: Neurotoxicological Targets from Functional Genomics and Proteomics Volume 5. Edited by: DJ Beadle, IR Mellor, PNR Usherwood. SCI (London); 2004:5I-58.

15. Mancini I, Sicurelli A, Guella G, Turk T, Maèek P, Sepčić K: Synthesis and bioactivity of linear oligomers related to polymeric alkylpyridinium metabolites from the Mediterranean sponge Reniera sarai. Org Biomol Chem 2004, 2:1368-1375.

16. Ahmed OAA, Adjimatera N, Pourzand C, Blagbrough IS: N4, N9-Dioleoyl spermine is a novel nonviral lipopolyamine vector for plasmid DNA formulation. Pharm Res 2005, 22:972-980.

17. Felgner PL, Barenholz Y, Behr JP, Cheng SH, Cullis P, Huang L, Jessee JA, Seymour L, Szoka F, Thierry AR, Wagner E, Wu G: Nomenclature for synthetic gene delivery systems. Hum Gene Ther 1997, 8:5||-5|2.

18. Geall AJ, Taylor RJ, Earll ME, Eaton MAW, Blagbrough IS: Synthesis of cholesteryl polyamine carbamates: $\mathrm{pK}$ (a) studies and condensation of calf thymus DNA. Bioconj Chem 2000, I I:3 I4-326.

19. Volk CA, Köck M: Viscosaline: new 3-alkyl pyridinium alkaloid from Arctic sponge Haliclona viscosa. Org Biomol Chem 2004, 2:1827-1830.

20. Volk CA, Lippert H, Lichte E, Köck M: Two new haliclamines from the arctic sponge Haliclona viscosa. Eur J Org Chem 2004, 2004:3।54-3I58.

21. Volk CA, Köck M: Viscosamine: The first naturally occurring trimeric 3-alkyl pyridinium alkaloid. Org Lett 2003, 5:3567-3569.

22. Gossen M, Bujard H: Tight Control of Gene-Expression in Mammalian-Cells by Tetracycline-Responsive Promoters. Proc Natl Acad Sci USA 1992, 89:5547-555I.

23. Muller RT, Honnert U, Reinhard J, Bahler M: The rat myosin myr 5 is a GTPase-activating protein for Rho in vivo: Essential role of arginine 1695. Mol Biol Cell 1997, 8:2039-2053.

24. Stoffler HE, Honnert U, Bauer CA, Hofer D, Schwarz H, Muller RT, Drenckhahn D, Bahler M: Targeting of the myosin-I myr 3 to intercellular adherens type junctions induced by dominant active Cdc42 in HeLa cells. J Cell Sci 1998, I I I:2779-2788. 